International Journal of Instruction e-ISSN: 1308-1470 • www.e-iji.net

Article submission code: 20200905030512

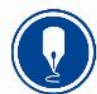

October $2021 \bullet$ Vol.14, No.4

p-ISSN: 1694-609X

pp. 357-372

Received: 05/09/2020

Revision: 16/03/2021

Accepted: 08/04/2021

OnlineFirst: 02/08/2021

\title{
Relationship between Total Personal Quality, Service Quality and Student Satisfaction on Higher Education System
}

\section{Nathanael Sitanggang}

Dr., corresponding author, Department of Building Engineering Education, Faculty of Engineering, Universitas Negeri Medan, Indonesia, nathanaelsitanggang@ unimed.ac.id

Putri Lynna Adelinna Luthan

Dr., Department of Civil Engineering Education, Faculty of Engineering, Universitas Negeri Medan, Indonesia, putri.lynna@unimed.ac.id

\section{Abdul Hamid K}

Department of Building Engineering Education, Faculty of Engineering, Universitas Negeri Medan, Indonesia, abdhamid_k@yahoo.co.id

Efforts to increase student satisfaction as higher education customers need to be made, since student satisfaction is related to the university quality. This research aimed to study the model of student satisfaction as university customers by using survey method. The sample was determined to be 208 people who were obtained by proportional random sampling. The instrument used was a questionnaire with questions of total student quality, quality of lecturer service, and student satisfaction as higher education customers, with the reliability coefficients of 0.82 , 0.84, and 0.86, respectively. Moreover, SEM analysis techniques using AMOS tools were conducted. Based on the results of the confirmatory factor analysis, Several points have been obtained, such as: (1) personal leadership is the strongest indicator $(69.38 \%$ ) to form the total quality student variable, (2) responsiveness is the strongest indicator $(81.90 \%)$ to form the quality of lecturer service variable, and (3) satisfaction is the strongest indicator (78.49\%) to form the student satisfaction as university customers variable. Furthermore, the analysis result found that the total personal quality of students had no significant effect on the testing of student satisfaction variables as university customers, However, the service quality variable had a positive effect on the student satisfaction. The results of this study will strengthen the student satisfaction model in higher education management and contribute to the education management science.

Keywords: total personal quality, lecturer service quality, student satisfaction, higher education system, university quality

Citation: Sitanggang, N., Luthan, P. L. A., \& Hamid K, A. (2021). Relationship between Total Personal Quality, Service Quality and Student Satisfaction on Higher Education System. International Journal of Instruction, 14(4), 357-372. https://doi.org/10.29333/iji.2021.14421a 


\section{INTRODUCTION}

Student satisfaction as higher education customers is very important to be assessed since the quality of a higher education institution can be seen from the level of student satisfaction (Butt \& Rehman, 2010; de Jager \& Gbadamosi, 2013; Yang et al., 2013). Students as members of the academic community are customers of a university (Arcaro, 2006). Although there are those who call students internal customers, students in universities are also considered as external customers (Sallis, 2002). As the university customer, student satisfaction is the most important aspect to be maintained in a college. Furthermore, satisfaction can be defined in various forms (Mosahab et al., 2010). It is not only defined as a relationship between expectations and behavior, but also as a relationship between quality and satisfaction. Based on the explanation above, it can be interpreted that the satisfaction is strongly related to the service quality. In addition, satisfaction is a core concept for loyalty. Students who are satisfied with the service of a university will strengthen their loyalty (Tjiptono \& Chandra, 2016).

The compliance of students in carrying out the discipline of university life and completing all assignments given by the lecturer in the learning process can be concluded as an evidence of stronger loyalty. Moreover, regarding the type of satisfaction and type of someone's dissatisfaction, it can be interpreted that students who are satisfied with the services of a university will feel optimistic and trustworthy (Tjiptono \& Chandra, 2016). But on the contrary, if students feel dissatisfied, it tends to generate protests and reduce the student's loyalty to higher education institutions. Therefore, higher education institutions must always strive to continuously improve service quality, both academic and administrative services. Furthermore, customer satisfaction acts as a mediator in the relationship between service quality and behavioral interest (Tjiptono \& Chandra, 2016), as illustrated in Figure 1 below.

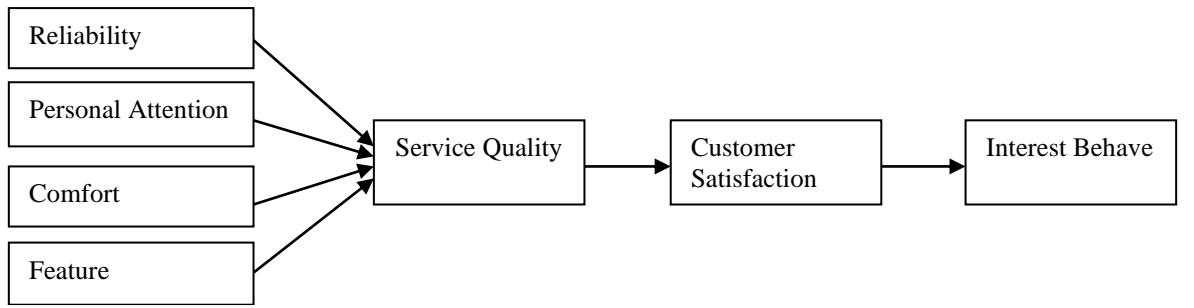

Figure 1

Variables affecting the customer satisfaction

Figure 1 describes that customer satisfaction is affected by service quality. The ACSI (American Customer Satisfaction Index) model also describes that customer satisfaction is influenced by perceived quality. Perception of quality is a measure of student evaluation of the quality of lecturer service in a tertiary institution. Moreover, service quality is influenced by expected service and perceived service. If the service of the lecturer is in accordance with the student's expectations, the quality of the service for the lecturer is perceived as good. Also, if the lecturer service exceeds the student's 
expectation, then the lecturer service quality is perceived as an ideal quality, resulting a very satisfied student. However, if the lecturers 'services are not in accordance with the expectations of students, the quality of the lecturers' services is perceived as bad, making the students feel dissatisfied. Thus, student satisfaction in higher education is influenced by the quality of lecturer service.

The quality of lecturer service can be divided into three dimensions, namely technical quality, quality of service behavior, and mental organizational members (Mosahab et al., 2010). Moreover, quality academic service has five dimensions, namely: physical dimensions (tangibles), dimensions of reliability (reliability), dimensions of responsibility or attention (responsiveness), dimensions of assurance (assurance), and dimensions of empathy (empathy) (Sukrisno, 2011). Tangibles means that lecturers must be able to use technological devices in each lecture process. Reliability is where lecturers need to be consistent according to the lecture contract guidance during the teaching process. Responsiveness is the willingness of the lecturer to serve students sincerely, so that students could obtain clear information. Assurance means that lecturers must be able to provide service guarantees to increase student confidence in higher education system. Lastly, empathy is defined as lecturers must be able and willing to pay attention to students personally, so that they can understand the desires of students as university customers.

Based on the description above, student satisfaction as a customer cannot be separated from the individual aspects of the student, such as total personal quality. The total quality of the person is defined as the individual's ability to self-management. Then, a person who can manage himself is categorized as a person who is able to lead (Abid et al., 2021; Lu et al., 2018; Thareja, 2012). Leading yourself is more difficult than leading others since leading other people is usually based on an assignment from an authorized official. Someone who has good personal leadership will certainly be able to construct a good plan. A person must be able to arrange the things that will be achieved in the future and plan of what efforts should be made to achieve them. Someone who has personal leadership and good planning aspect can be classified as a total quality person (Gaspersz, 2013). If the above description is related to students, then the total quality of the person is the ability of students to lead themselves, have a clear planning aspect, and strive to improve themselves in a sustainable manner. Students who can lead themselves naturally tend to be disciplined and obey regulation. Also, students who have good planning will certainly focus on their lecture program and be able to manage their time. In addition, if the student already knows his weakness, then the student tries to improve it on an ongoing basis.

Managing "time" is very important for students because the lecture system in higher education in Indonesia is a semester credit unit (SKS) which is always linked to time management. Based on the introduction and theoretical description above, this research tried to investigate the relationship between each indicator to the student's total personal quality, lecturer service quality and student satisfaction as a university costumer variable. In addition, this research investigated total personal quality and service quality 
effect on customer satisfaction as a hypothesis. Based on these findings, model that describe student satisfaction as university costumer would be found.

\section{METHOD}

This research was aimed to study the model of student satisfaction as customers in higher education. The population number was 3,822 education students of academic class of 2016. The sampling technique was purposive random sampling, with the sample number determination was following the Yamane formula (Singh \& Masuku, 2014), to obtain a total sample of 208 people.

This research used a survey method by using a questionnaire (Jonker et al., 2010). The questionnaire was developed by researchers based on theories of total personal quality, service quality, and customer satisfaction based on a Likert scale with 5 choices, namely: strongly disagree, disagree, neutral, agree, and strongly agree. Every instrument was initially tested to determine its validity and reliability. To test the validity of the instrument, the product moment correlation analysis technique from Karl Pearson was used, while Alpha coefficient formula was used to calculate the instrument reliability coefficient (Taber, 2018).

Based on the results of the test data analysis, it turns out that from the 36 items of the total personal quality questionnaire, as many as 32 valid items were obtained with the reliability coefficient of 0.82 . From the 36 questionnaire items on the quality of lecturer service, 31 items were valid with the reliability coefficient of 0.84 . Lastly, from 36 items of the student satisfaction questionnaire as a customer, there are 32 valid items and with reliability coefficient of 0.86 . It was concluded that the reliability coefficients of the three instruments are high and significant.

Confirmatory factor analysis and SEM analysis techniques using AMOS tools was used (Arbuckle, 2012). Confirmatory factor analysis was used to determine the relationship between indicators for each latent variable, while SEM analysis techniques using AMOS tools were used for hypothesis testing. SEM analysis technique is suitable for use in this study because it meets the requirements for using SEM analysis (Hair Jr. et al., 2010; Zuhri et al., 2016).

\section{FINDINGS}

\section{Confirmatory Factor Analysis}

Confirmatory factor analysis was performed to identify the right model that explains the relationship between each of the indicators forming the latent construct variables. In this research, there are 3 latent variables consisting of 11 indicators. The research variable construct model is displayed in Figure 2 and Table 1. 


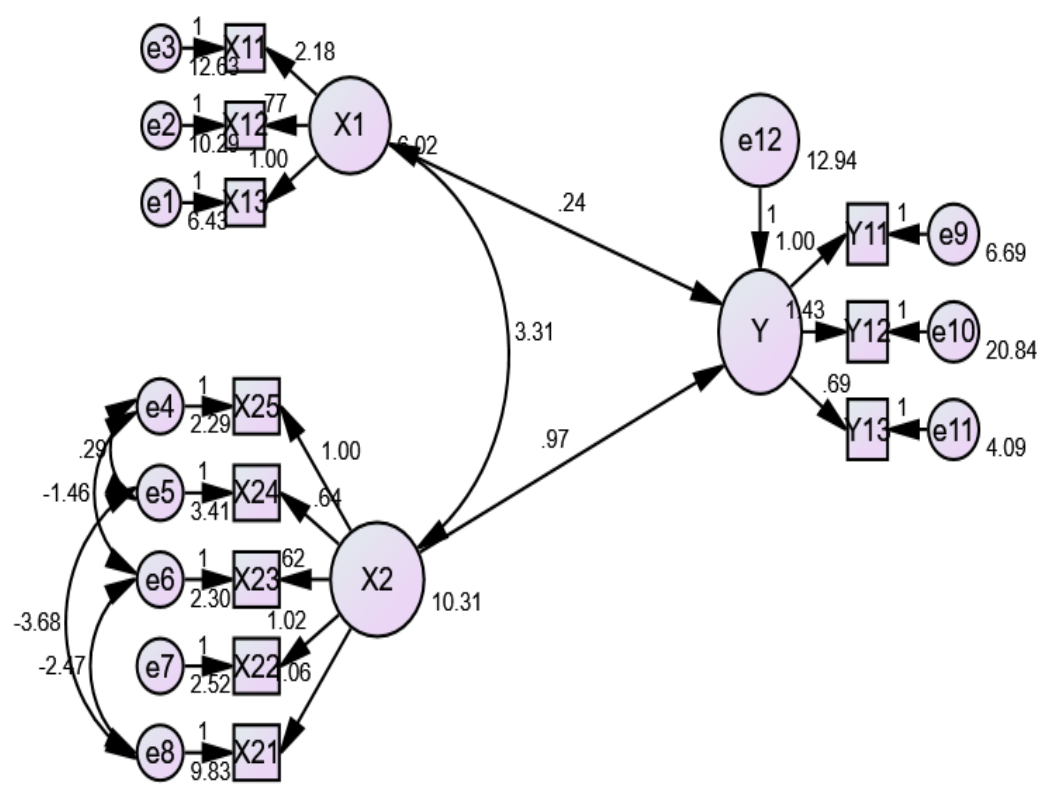

Figure 2

Research variable construct model

Note:

$\mathrm{X} 1$ = Total personal quality of students $\mathrm{Y}=$ Students satisfaction as a customer

$\mathrm{X} 11=$ Personal leadership

Y11 = Satisfaction towards product

$\mathrm{X} 12=$ Planning

Y12 $=$ Satisfaction towards services

$\mathrm{X} 13=$ Continuous improvement

Y13= Satisfaction towards supplies

$\mathrm{X} 2$ = Lecturer service quality

$\mathrm{X} 21=$ reliability

$\mathrm{X} 22=$ assurance

$\mathrm{X} 23=$ tangibles

$\mathrm{X} 24=$ empathy

$\mathrm{X} 25=$ responsiveness 
Table 1

Standardized regression weights

\begin{tabular}{|c|c|c|c|c|}
\hline & & Estimate & $\begin{array}{l}\text { Percentage } \\
\text { of Estimated } \\
\text { Squares }(\%)\end{array}$ & Description \\
\hline X13 <--- & $\mathrm{X} 1$ & 0.695 & 48.30 & $\begin{array}{l}48.30 \% \text { variations in indicators of continuous } \\
\text { improvement can explain the construct of total } \\
\text { personal quality }\end{array}$ \\
\hline X12 <--- & $\mathrm{X} 1$ & 0.505 & 25.50 & $\begin{array}{l}25.50 \% \text { variations in indicators of continuous } \\
\text { improvement can explain the construct of total } \\
\text { personal quality }\end{array}$ \\
\hline X11 <--- & $\mathrm{X} 1$ & 0.833 & 69.38 & $\begin{array}{l}69.38 \% \text { variations in indicators of continuous } \\
\text { improvement can explain the construct of total } \\
\text { personal quality }\end{array}$ \\
\hline X25 <--- & $\mathrm{X} 2$ & 0.905 & 81.90 & $\begin{array}{l}81.90 \% \text { variations in responsiveness indicators can } \\
\text { explain the constructs of the quality of lecturer } \\
\text { service }\end{array}$ \\
\hline X24<--- & $\mathrm{X} 2$ & 0.745 & 55.50 & $\begin{array}{l}55.50 \% \text { variations in empathy indicators can explain } \\
\text { the constructs of the quality of lecturer service }\end{array}$ \\
\hline X23 <--- & $\mathrm{X} 2$ & 0.798 & 63.68 & $\begin{array}{l}63.68 \% \text { variations in tangibles indicators can } \\
\text { explain the constructs of the quality of lecturer } \\
\text { service }\end{array}$ \\
\hline X22<--- & $\mathrm{X} 2$ & 0.900 & 81.00 & $\begin{array}{l}81.00 \% \text { variations in assurance indicators can } \\
\text { explain the constructs of the quality of lecturer } \\
\text { service }\end{array}$ \\
\hline X21<--- & $\mathrm{X} 2$ & 0.734 & 53.87 & $\begin{array}{l}53.87 \% \text { variations in reliability indicators can } \\
\text { explain the constructs of the quality of lecturer } \\
\text { service }\end{array}$ \\
\hline Y13<--- & $\mathrm{Y}$ & 0.861 & 74.13 & $\begin{array}{l}74.13 \% \text { variations in the satisfaction indicators of } \\
\text { supplies can explain the constructs of student } \\
\text { satisfaction as customers }\end{array}$ \\
\hline Y12 <--- & $\mathrm{Y}$ & 0.841 & 70.72 & $\begin{array}{l}70.72 \% \text { variations in indicators of satisfaction with } \\
\text { service can explain the constructs of student } \\
\text { satisfaction as customers }\end{array}$ \\
\hline Y11<--- & $\mathrm{Y}$ & 0.886 & 78.49 & $\begin{array}{l}78.49 \% \text { Variations in product satisfaction indicators } \\
\text { can explain the constructs of student satisfaction as } \\
\text { customers }\end{array}$ \\
\hline
\end{tabular}

\section{Model Evaluation}

Table 2 shows that the goodness of fit model has all the criteria with good results. Therefore, it can be interpreted that the model's ability to explain the predetermined variable relationships is very good. Furthermore, the results of the calculation of the chi square test obtained a value of 46.981 and $p$ value $=0.126>\alpha=0.01$. Therefore, it can be concluded that the model is fit with existing data and variable constructs can be processed with a full model. 
Table 2

Model evaluation results

\begin{tabular}{llllllllll}
\hline & $\chi^{2}$ & Prob. & RMSEA & GFI & AGFI & CMIN & PCMIN & TLI & CFI \\
\hline $\begin{array}{l}\text { Cut-off } \\
\text { Value }\end{array}$ & Small & $>0,05$ & $<0.08$ & $>0.9$ & $>0.9$ & $<2$ & $>0.05$ & $>0.9$ & $>0.9$ \\
\hline Output & 46.981 & 0.126 & 0.038 & 0.955 & 0.920 & 1.270 & 0.126 & 0.988 & 0.992 \\
\hline Decision & Good & Good & $\begin{array}{l}\text { Model } \\
\text { Fit }\end{array}$ & Good & Good & $\begin{array}{l}\text { Model } \\
\text { Fit }\end{array}$ & $\begin{array}{l}\text { Model } \\
\text { Fit }\end{array}$ & $\begin{array}{l}\text { Model } \\
\text { Fit }\end{array}$ & $\begin{array}{l}\text { Model } \\
\text { Fit }\end{array}$ \\
\hline
\end{tabular}

Based on table 2, it can be seen that the goodness of fit model has all the criteria with good results, then it can be interpreted that the model's ability to explain the predetermined variable relationships is categorized as very good.

\section{Relationship Analysis Between Each Constructs}

The relationship between constructs can be seen based on regression weights on the AMOS output which is presented in Table 3.

Table 3

Regression weights

\begin{tabular}{lllllll}
\hline & & & Estimate & S.E. & C.R. & $p$ \\
\hline $\mathrm{Y}$ & $<---$ & $\mathrm{X} 1$ & .242 & .153 & 1.583 & .113 \\
\hline $\mathrm{Y}$ & $<---$ & $\mathrm{X} 2$ & .968 & .117 & 8.300 & $* * *$ \\
\hline $\mathrm{X} 13$ & $<---$ & $\mathrm{X} 1$ & 1.000 & & & \\
\hline $\mathrm{X} 12$ & $<---$ & $\mathrm{X} 1$ & .766 & .130 & 5.870 & $* * *$ \\
\hline $\mathrm{X} 11$ & $<---$ & $\mathrm{X} 1$ & 2.182 & .318 & 6.856 & $* * *$ \\
\hline $\mathrm{X} 25$ & $<---$ & $\mathrm{X} 2$ & 1.000 & & & \\
\hline $\mathrm{X} 24$ & $<---$ & $\mathrm{X} 2$ & .642 & .047 & 13.522 & $* * *$ \\
\hline $\mathrm{X} 23$ & $<---$ & $\mathrm{X} 2$ & .624 & .054 & 11.565 & $* * *$ \\
\hline $\mathrm{X} 22$ & $<---$ & $\mathrm{X} 2$ & 1.021 & .058 & 17.724 & $* * *$ \\
\hline $\mathrm{X} 21$ & $<---$ & $\mathrm{X} 2$ & 1.056 & .085 & 12.393 & $* * *$ \\
\hline $\mathrm{Y} 11$ & $<---$ & $\mathrm{Y}$ & 1.000 & & & \\
\hline $\mathrm{Y} 12$ & $<---$ & $\mathrm{Y}$ & 1.432 & .097 & 14.773 & $* * *$ \\
\hline $\mathrm{Y} 13$ & $<---$ & $\mathrm{Y}$ & .690 & .045 & 15.292 & $* * *$ \\
\hline $\mathrm{N} 016:$ & $<-01$ & $\mathrm{Sign}$ & & &
\end{tabular}

Note: $p<\alpha=0.01$ (Significant)

Table 3 describes that the total personal quality variable does not have a significant relationship with the student satisfaction variable as a customer, with a $p$ value 0.113 . Meanwhile, the lecturer service quality variable has a significant relationship with the student satisfaction variable as a customer, with a $p$ value 0.00 .

\section{Direct, Indirect and Total Effects}

The direct, indirect, and total effects between variables are summarized in Table 4, Table 5, and Table 6 respectively. 
Table 4

Standardized direct effects

\begin{tabular}{llll}
\hline & $\mathrm{X} 2$ & $\mathrm{X} 1$ & $\mathrm{Y}$ \\
\hline $\mathrm{Y}$ & .628 & .120 & .000 \\
\hline $\mathrm{Y} 13$ & .000 & .000 & .861 \\
\hline $\mathrm{Y} 12$ & .000 & .000 & .841 \\
\hline $\mathrm{Y} 11$ & .000 & .000 & .886 \\
\hline $\mathrm{X} 21$ & .734 & .000 & .000 \\
\hline $\mathrm{X} 22$ & .900 & .000 & .000 \\
\hline $\mathrm{X} 23$ & .798 & .000 & .000 \\
\hline $\mathrm{X} 24$ & .745 & .000 & .000 \\
\hline $\mathrm{X} 25$ & .905 & .000 & .000 \\
\hline $\mathrm{X} 11$ & .000 & .833 & .000 \\
\hline $\mathrm{X} 12$ & .000 & .505 & .000 \\
\hline $\mathrm{X} 13$ & .000 & .695 & .000 \\
\hline
\end{tabular}

Based on table 4, it can be concluded that the most direct influence that affects student satisfaction as a customer is the exogenous variable of lecturer service quality with the value of 0.628 , compared with the direct effect of the exogenous variable on total personal quality of students with the value of 0.120 .

Table 5

Standardized indirect effects

\begin{tabular}{llll}
\hline & $\mathrm{X} 2$ & $\mathrm{X} 1$ & $\mathrm{Y}$ \\
\hline $\mathrm{Y}$ & .000 & .000 & .000 \\
\hline $\mathrm{Y} 13$ & .540 & .103 & .000 \\
\hline $\mathrm{Y} 12$ & .528 & .101 & .000 \\
\hline $\mathrm{Y} 11$ & .556 & .106 & .000 \\
\hline $\mathrm{X} 21$ & .000 & .000 & .000 \\
\hline $\mathrm{X} 22$ & .000 & .000 & .000 \\
\hline $\mathrm{X} 23$ & .000 & .000 & .000 \\
\hline $\mathrm{X} 24$ & .000 & .000 & .000 \\
\hline $\mathrm{X} 25$ & .000 & .000 & .000 \\
\hline $\mathrm{X} 11$ & .000 & .000 & .000 \\
\hline $\mathrm{X} 12$ & .000 & .000 & .000 \\
\hline $\mathrm{X} 13$ & .000 & .000 & .000 \\
\hline
\end{tabular}

Based on table 5, the construct variable of lecturer service quality gives an indirect effect on each indicator of student satisfaction as a customer, namely 0.556 on the indicator of product satisfaction, 0.540 on the satisfaction indicator for supplies, and 0.528 on the indicator of satisfaction with service. With the similar pattern, the student's total personal quality construct variable also shows an indirect effect on each indicator of student satisfaction as a customer, namely 0.106 on the satisfaction indicator for the 
product, 0.103 on the satisfaction indicator for supplies, and 0.101 on the satisfaction with the service.

Table 6

Standardized total effects

\begin{tabular}{llll}
\hline & $\mathrm{X} 2$ & $\mathrm{X} 1$ & $\mathrm{Y}$ \\
\hline $\mathrm{Y}$ & .628 & .120 & .000 \\
\hline $\mathrm{Y} 13$ & .540 & .103 & .861 \\
\hline $\mathrm{Y} 12$ & .528 & .101 & .841 \\
\hline $\mathrm{Y} 11$ & .556 & .106 & .886 \\
\hline $\mathrm{X} 21$ & .734 & .000 & .000 \\
\hline $\mathrm{X} 22$ & .900 & .000 & .000 \\
\hline $\mathrm{X} 23$ & .798 & .000 & .000 \\
\hline $\mathrm{X} 24$ & .745 & .000 & .000 \\
\hline $\mathrm{X} 25$ & .905 & .000 & .000 \\
\hline $\mathrm{X} 11$ & .000 & .833 & .000 \\
\hline $\mathrm{X} 12$ & .000 & .505 & .000 \\
\hline $\mathrm{X} 13$ & .000 & .695 & .000 \\
\hline
\end{tabular}

Finally, table 6 describes that the largest total effect is given by the variable quality of lecturer service (X2) on the variable student satisfaction as a customer (Y) with the value of 0.628 . On the other hand, it turns out that the personal leadership indicator (X11) has the largest total effect on the student's total personal quality variable (X1) with the value of 0.833 . The responsiveness indicator (X25) has the largest total effect on the variable of lecturer service quality (X2) amounting to 0.905 , while the indicator of product satisfaction (Y11) gives the largest total effect on the student satisfaction variable as a customer $(\mathrm{Y})$ with the value 0.886 .

\section{DISCUSSION}

\section{Confirmatory Factor Analysis}

Based on the analysis, all the forming indicators of each latent construct variable have a critical ratio (CR) with a probability value of $p<\alpha=0.01$ and have met the predetermined goodness of fit criteria. Therefore, the measurement model is accurate to be an indicator of the measured construct variables and fit with the existing data. Based on Table 1, the percentage of the relationship of each indicator can be sorted on the latent construct variable. The latent construct variables of total personal quality are formed by $69.38 \%$ indicators of personal leadership, $25.50 \%$ of planning, and $48.30 \%$ of continuous improvement. The results of this analysis indicate that the personal leadership indicator is the strongest indicator to form latent construct variables of total personal quality. Individuals who have personal leadership and good planning aspects can be classified as total quality individuals (Gaspersz, 2013). Furthermore, the selfmanagement is important for everyone because of the collection of behavioural and cognitive strategies that a person uses to influence and improve his own behaviour 
(Yukl, 2002). Finally, the importance of self-leadership skills also needs to be raised, so that you can be grateful for your strength and collaborate for success (Blanchard, 2007).

The latent construct variable for the quality of lecturer service is formed by $53.87 \%$ of reliability indicator, $81.00 \%$ of assurance indicator, $63.68 \%$ of tangibles indicator, $55.50 \%$ of empathy indicator, and $81.90 \%$ of responsiveness indicator. These results indicate that the indicators of responsiveness and assurance are the strongest indicators to form the latent construct variables of the quality of lecturer services. The results of this study corelate to previous research which discovered that quality academic services consist of five dimensions, namely: tangibles, reliability, responsiveness, assurance, and empathy (Sukrisno, 2011). However, in this study and with the context of higher education, the order of the five dimensions based on the magnitude of the influence on the quality of lecturer service variables was found to be responsiveness, assurance, tangibles, empathy, and reliability.

Furthermore, the latent construct variables of student satisfaction as customers are formed by $78.49 \%$ of satisfaction indicators for products, $70.72 \%$ of satisfaction with services, and $74.13 \%$ of satisfaction with supplies. The results of this analysis indicate that the indicator of product satisfaction is the strongest indicator of latent construct variables of student satisfaction as customers. The results of this study are in line with the findings of previous research. Although the context is in the automotive industry, it was found that $77.20 \%$ of product quality influences customer satisfaction (Jahanshahi et al., 2011).

\section{Model Evaluation}

In Figure 2, the research variable construct model used as a structural model for the AMOS output in this study has been provided. Before evaluating the model, it is necessary to fulfill the assumptions as required for the SEM analysis technique (Arbuckle, 2012; Sasongko et al., 2016). Fulfilling the assumptions consists of three steps, namely: 1) testing the construct validity; 2) performing a suitability test and statistical test on the research model, based on the suitability index, cut-off value; and 3) model interpretation. The first step is to test the construct validity by using CFA (Confirmatory Factor Analysis). The second step, the model suitability test and statistical tests were analysed by: (1) Chi-square statistics, the research model is declared good if the resulting chi-square value is low and the probability with a cut-off value of $p>\alpha=0.05$; (2) CFI (Comparative Fit Index), the value is between 0 and 1.0. If CFI $>0.90$, the model is declared good fit, while if the value is $0.80<\mathrm{CFI}<0.90$, the model is declared marginal fit; (3) TLI (Tucker-Lewis Index), values from 0 to 1.0. If TLI $>0.90$, then the model is declared good fit, and if the value is $0.80<\mathrm{TLI}<0.90$, the model is declared marginal fit; (4) GFI (Goodness of Fit Index), is a non-statistical measure with a range of values from 0 (poor fit) to 1.0 (perfect fit). If GFI $>0.90$, then the model is declared good fit, and if the value is $0.80<\mathrm{GFI}<0.90$, the model is declared marginal fit; (5) AGFI (Adjusted Goodness of Fit Index), the value is from 0 to 1.0. If the value of AGFI is $>0.90$, then the model is declared good fit, and if the value is $0.80<$ AGFI $<0.90$, the model is declared marginal fit; and (6) RMSEA (The Root Mean 
Square Error of Approximation), showing the expected goodness of fit. If the RMSEA value $<0.08$, the model is declared a good fit. Furthermore, the third step is to interpret the results of the analysis of the magnitude of the influence or contribution of indicator variables to latent variables and the magnitude of the influence between latent construct variables.

The results of testing the analysis requirements show: 1) The assumption of the number of research samples has been fulfilled ( sample $=208>$ minimum sample $=110$ ); 2) The data normality test was performed using the critical ratio skewness criteria of \pm 3.00 at the 0.01 significance value. The normality test results show that the value of c.r. skew and c.r. kurtosis is in the range of -2.58 to +2.58 . Then, it can be stated that the research data has met the assumption of normality; Finally, 3) testing of outliers was conducted by obtaining the recommended value of the Chi-square coefficient which was small. The test results for the outliers showed that the Chi-square value was 46.981 with $p=0.000$ $<\alpha=0.01$. This means that the data used in the model is the same as the data used in model development. Based on the fulfillment of the above assumptions, the model evaluation can be carried out. The results of the model evaluation are described in Table 2.

\section{Relationship Analysis Between Each Constructs}

Table 3 shows that the student's total personal quality variable does not show a significant relationship to the student satisfaction variable as a university customer, with a value of $p=0.113>(\alpha=0.01)$. Meanwhile, the variable of lecturer service quality has a significant relationship with the variable of student satisfaction as university customers, with a value of $p=0.00<(\alpha=0.01)$. As it is known, the total personal quality factor of a student is an aspect of individual characteristics in an integrative model of organizational behaviour that individual characteristics (personality, cultural values, and abilities) possess a direct effect on job satisfaction (Colquitt et al., 2009). However, in this study, the variable personal total quality of students did not have a significant relationship with student satisfaction as customers. This is due to a difference between student satisfaction as university customers and job satisfaction.

\section{Direct, Indirect and Total Effects}

Table 4 indicates that the biggest direct influence affecting student satisfaction as university customers is the exogenous variable of the quality of lecturers' service with the value of 0.628 , compared with the direct effect of the exogenous variable on the total personal quality of students with the value of only 0.120 . The results illustrate that student satisfaction as higher education customers are strongly influenced by the quality of lecturer service at $39.43 \%$. The results of this research were in accordance with the findings of several research (Jahanshahi et al., 2011; Khoo et al., 2017; Mosahab et al., 2010).

These findings can also support the model of the relationship between service quality and customer satisfaction that has been found in other contexts outside educational institutions. In the telecommunication context, it was found that $58 \%$ of service quality 
was significantly correlated with customer satisfaction (Ashraf, Muhammad Aqeel, Niazi \& Zafar, 2018). Likewise, another study found that a $100 \%$ change in service quality would be able to change $92.5 \%$ of customer satisfaction (Malik et al., 2012). In the context of Retail Banking, it was found that service quality has a significant direct effect on customer satisfaction by 0.400 and an indirect effect on customer loyalty by 0.528 (Ngo \& Nguyen, 2016). However, this finding differs from a study which discovered that service quality has no significant effect on student satisfaction and loyalty (Qomariah, 2012). In addition, several factors that affect student satisfaction are categorized as public or private institution service (Ibrahim et al., 2012), gender and university difference (de Jager \& Gbadamosi, 2013), academic service, administrative service and facility (Bhuian, 2016), perceived value, image, expectation, quality of hardware, and quality of software (Shahsavar \& Sudzina, 2017) and students oriented service (Ozdemir et al., 2020)

Table 5 shows that the indirect influence of the construct variable quality of lecturer service shows the same pattern as the indirect effect of the construct variable of the student's total personal quality on each indicator of student satisfaction as a customer. Both of which have an indirect effect on the indicator of student satisfaction, which is in the same order, namely satisfaction indicators for products (Y11), indicators of satisfaction with supplies (Y13), and indicators of satisfaction with services (Y12). In particular, the construct variable of lecturer service quality has an indirect effect on each indicator of student satisfaction as a customer, namely 0.556 on the indicator of product satisfaction, 0.540 on the satisfaction indicator for supplies, and 0.528 on the satisfaction indicator for service. Similarly, the student's total personal quality construct variable has an indirect effect on each indicator of student satisfaction as a customer, namely 0.106 on the satisfaction indicator for the product, 0.103 on the satisfaction indicator for supplies, and 0.101 on the satisfaction with the service.

Table 6 shows that the largest total effect is given by the lecturer service quality (X2) towards the student satisfaction as a customer (Y) with the value of 0.628 . In terms of largest total effect among indicators on the construct variable, it turns out that the personal leadership indicator (X11) has the largest total effect on the total personal quality variable of students (X1) with 0.833 . The responsiveness indicator (X25) has the largest total effect on the variable of lecturer service quality (X2) amounting to 0.905 , and the indicator of product satisfaction (Y11) gave the largest total effect on the student satisfaction variable as a customer $(\mathrm{Y})$ with the value of 0.886 .

\section{CONCLUSION}

Student satisfaction as customers in a university is very important to be continuously reviewed to ensure the quality of service at the college. Student satisfaction variables as customers are never obsolete to be studied, because of the exchange of new students every year. Empirically, the quality of lecturer service has a greater influence on student satisfaction as customers than the effect on the total personal quality of students. These findings will strengthen the satisfaction theory model in higher education management.

This research has limitations because it only investigated student satisfaction as 
customers in higher education. Also, researchers only studied the influence of the total personal quality variables of students and the variables of the quality of lecturer services, with other possible factors that can theoretically affect student satisfaction. However, the findings of this study is expected to open the opportunities for further researchers to conduct a research with broader scope and from outside of higher education institutions.

\section{ACKNOWLEDGEMENTS}

Authors would like to thank Directorate of Research and Community Service Ministry of Research, Technology and Higher Education of Indonesia. Also, authors send gratitude to Rector of Universitas Negeri Medan, Indonesia.

\section{REFERENCES}

Abid, G., Arya, B., Arshad, A., Ahmed, S., \& Farooqi, S. (2021). Positive personality traits and self-leadership in sustainable organizations: Mediating influence of thriving and moderating role of proactive personality. Sustainable Production and Consumption, 25, 299-311. https://doi.org/10.1016/j.spc.2020.09.005

Arbuckle, J. L. (2012). IBM, SPSS, AMOS 21 User's Guide. Amos Development Corporation.

Arcaro, J. S. (2006). Quality Based Education of Principles of Formulation and Implementation Procedures. Penerbit Pustaka Pelajar.

Ashraf, Muhammad Aqeel, Niazi, A. A. K., \& Zafar, U. (2018). Impact of Brand Image, Service Quality and Trust on Customer Loyalty, Moderating Effect of Perceived Price Fairness and Mediating Effect of Customer Satisfaction: Case Study on Telecommunication Sector of Pakistan. International Journal of Business Marketing and Management, 3(10), 8-20.

Bhuian, S. N. (2016). Sustainability of Western branch campuses in the Gulf Region: Students' perspectives of service quality. International Journal of Educational Development, 49, 314-323. https://doi.org/10.1016/j.ijedudev.2016.05.001

Blanchard, K. (2007). Leading at a Higher Level: Blanchard on Leadership and Creating High Performance Organizations. Pearson Education.

Butt, B. Z., \& Rehman, K. U. (2010). A study examining the students satisfaction in higher education. Procedia - Social and Behavioral Sciences, 2(2), 5446-5450. https://doi.org/10.1016/j.sbspro.2010.03.888

Colquitt, J. A., Lepine, J. A., \& Wesson, M. J. (2009). Organizational Behavior Improving Performance and Commitment in the Workplace. Mc Graw-Hill Companies, Inc. 
de Jager, J., \& Gbadamosi, G. (2013). Predicting students' satisfaction through service quality inhigher education. International Journal of Management Education, 11(3), 107-118. https://doi.org/10.1016/j.ijme.2013.09.001

Gaspersz, V. (2013). All-in-one Integrated Total Quality Talent Management. Tri-AlBros Publishing.

Hair Jr., J. F., Black, W. C., Babin, B. J., \& Anderson, R. E. (2010). Multivariate Data Analysis. Pearson Prentice Hall.

Ibrahim, M. Z., Rahman, M. N. A., \& Yasin, R. M. (2012). Assessing Students Perceptions of Service Quality in Technical Educational and Vocational Training (TEVT) Institution in Malaysia. Procedia - Social and Behavioral Sciences, 56, 272283. https://doi.org/10.1016/j.sbspro.2012.09.655

Jahanshahi, A. A., Gashti, M. A. H., Mirdamadi, S. A., Nawaser, K., \& Khaksar, S. M. (2011). Study the Effects of Customer Service and Product Quality on Customer Satisfaction and Loyalty. International Journal of Humanities and Social Science, 1(7), 253-260.

Jonker, J., Pennink, B., Jonker, J., \& Pennink, B. W. (2010). The Essence of Methodology. In The Essence of Research Methodology (pp. 21-41). Springer Berlin Heidelberg. https://doi.org/10.1007/978-3-540-71659-4_2

Khoo, S., Ha, H., \& McGregor, S. L. T. (2017). Service quality and student/customer satisfaction in the private tertiary education sector in Singapore. International Journal of Educational Management, 31(4), 430-444. https://doi.org/10.1108/JJEM-09-20150121

Lu, X., Xie, B., \& Guo, Y. (2018). The trickle-down of work engagement from leader to follower: The roles of optimism and self-efficacy. Journal of Business Research, 84, 186-195. https://doi.org/10.1016/j.jbusres.2017.11.014

Malik, M. E., Ghafoor, M. M., \& Iqbal, H. K. (2012). Impact of Brand Image, Service Quality and Price on Customer Satisfaction in Pakistan Telecommunication Sector. International Journal of Business and Social Science, 3(23), 123-129.

Mosahab, R., Mahamad, O., \& Ramayah, T. (2010). Service Quality, Customer Satisfaction and Loyalty: A Test of Mediation. International Business Research, 3(4), $72-80$.

Ngo, M. V., \& Nguyen, H. H. (2016). The Relationship between Service Quality, Customer Satisfaction and Customer Loyalty: An Investigation in Vietnamese Retail Banking Sector. Journal of Competitiveness, 8(2), 103-116. https://doi.org/10.7441/joc.2016.02.08

Ozdemir, Y., Kaya, S. K., \& Turhan, E. (2020). A scale to measure sustainable campus services in higher education: "Sustainable Service Quality." Journal of Cleaner 
Production, 245, 118839. https://doi.org/10.1016/j.jclepro.2019.118839

Qomariah, N. (2012). Pengaruh Kualitas Layanan dan Citra Institusi terhadap Kepuasan dan Loyalitas Pelanggan (Studi pada Universitas Muhammadiyah di Jawa Timur) [The Effect of Service Quality and Institutional Image on Customer Satisfaction and Loyalty (Study at Muhammadiyah University in East Java)]. Jurnal Aplikasi Manajemen, 10(1), 177-187.

Sallis, E. (2002). Total Personal Quality Management in Education (3rd editio). Taylor \& Francis.

Sasongko, E. N., Mustafid, M., \& Rusgiyono, A. (2016). Penerapan Metode Structural Equation Modeling untuk Analisis Kepuasan Pengguna Sistem Informasi Akademik terhadap Kualitas Website (studi kasus pada website sia.undip.ac.id) [Application of Structural Equation Modeling Methods for Analysis of Academic Information towards Website Quality (case study on website sia.undip.ac.id)]. Jurnal Gaussian, 5(3), 395404.

Shahsavar, T., \& Sudzina, F. (2017). Student satisfaction and loyalty in Denmark: Application of EPSI methodology. PLOS ONE, 12(12), e0189576. https://doi.org/10.1371/journal.pone.0189576

Singh, A. S., \& Masuku, M. B. (2014). Sampling Techniques \& Determination of Sample Size in Applied Statistics Research: An Overview. International Journal of Economics, Commerce and Management, 2(11), 1-22.

Sukrisno, H. (2011). Akuntabilitas Mutu Pelayanan Perguruan Tinggi [Accountability of Higher Education Service Quality]. Jurnal Pendidikan Dan Pembelajaran, 18(1), 81-89.

Taber, K. S. (2018). The Use of Cronbach's Alpha When Developing and Reporting Research Instruments in Science Education. Research in Science Education, 48(6), 1273-1296. https://doi.org/10.1007/s11165-016-9602-2

Thareja, P. (2012). Personal Quality Improvement in Youth. SSRN Electronic Journal. https://doi.org/10.2139/ssrn.1650536

Tjiptono, F., \& Chandra, G. (2016). Service, Quality dan Satisfaction. CV. Andi Offset.

Yang, Z., Becerik-Gerber, B., \& Mino, L. (2013). A study on student perceptions of higher education classrooms: Impact of classroom attributes on student satisfaction and performance. Building and Environment, 70, 171-188. https://doi.org/10.1016/j.buildenv.2013.08.030

Yukl, G. (2002). Leadership in Organization (5th Editio). Prentice Hall.

Zuhri, S., Andriansyah, A., Asmadi, D., \& Khajar, S. (2016). Analisis Loyalitas Pelanggan Industri Jasa Pengiriman Menggunakan Structural Equation Modeling 
[Analysis of Customer Loyalty in the Shipping Service Industry Using Structural Equation Modeling]. Jurnal Ilmiah Teknik Industri, 15(2), 101-108. https://doi.org/https://doi.org/10.23917/jiti.v15i2.2558 